\title{
The Relation between Mental Verbs Utilization and Child Pragmatic Language Checklist Scores in a Story Retelling Task: 6 to 9 Aged Children
}

\author{
Eun Ju Lee \\ Department of Communication Disorders, Ewha Womans University, Seoul, Korea
}

Correspondence: Eun Ju Lee, PhD

Department of Communication Disorders,

Ewha Womans University, 52 Ewhayeodae-gil,

Seodamun-gu, Seoul 03760, Korea

Tel: $+82-2-3277-2120$

Fax: +82-2-3277-2122

E-mail: imfedra@naver.com

Received: June 24, 2019

Revised: August 2, 2019

Accepted: September 2, 2019

This work is based on a partial data from the first author's doctoral dissertation.

This work was supported by the BK21 plus funded by the Ministry of Education of Korea.
Objectives: Mental verbs are related to children's communication and language development, especially their reading comprehension and language skills. So, we examined whether the usage rate of mental verbs in a story task was related to the scores of the Children's Pragmatic Language Checklists (CPLC). Methods: In a "Retell the Story" task with 22 child participants, we examined the relationship between the story comprehension scores, usage rates by type of mental verb, and the usage rate of mental verbs by stage of sentence complexity and scores by four sub-regions of CPLC through Pearson product-moment association. We looked at the above correlation analysis to see if a regression model could be used to predict the pragmatic language proficiency score through variables that are significantly correlated. Results: IQ scores, REVT-E scores, cognitive verbs, psychological verbs, and perceptual verbs among mental verbs were found to be related to CPLC scores. IQ scores were significantly related communication intent scores $(t=2.583, p=.018)$. Also, the REVT-E score was significantly related the nonverbal communication score $(t=2.382, p<.027)$. These results are meaningful in that they show that communication skills are related to individual intelligence and vocabulary ability. In particular, the rate of usage of psychological verbs was significantly related to the ability of the child language checklist to contextual variation (CV; $r=45, p<.035)$. The rate of usage of psychological verbs was confirmed to be a variable for predicting CV score, and a description model was available $(F=5.12, p<.035)$. Conclusion: Although this study was limited to 22 participants, it is meaningful in that the degree of use of a particular vocabulary is related to, and predicts, pragmatic language skills.

Keywords: Mental verb, Psychological verb, Story retelling, Pragmatic language, CPLC
심성동사란 요구(desire), 믿음(belief), 의도(intention)에 대한 표 현을 할 때 주로 활용되는 동사어휘로, 마음 상태 또는 활동, 감정, 태도, 요구, 지각, 인지와 관련되며 일반적으로 만 3 세 정도에 출현 한다(Bartsch \& Wellman, 1995). 그리고 의사소통에 있어 중요한 역할을 하고 또한 언어발달에 있어 주요 발달지표가 되기도 한다 (Bartsch \& Wellman, 1995; Bretherton \& Beeghly, 1982; Montgomery, 2002). 예를 들어 의사소통을 할 때나 텍스트를 볼 때 가장 흔하게 접할 수 있는 심성동사는 "알다(know), 생각하다(think), 요구하다(ask), 가정하다(suppose), 짐작하다(guess)" 등과 같은 어 휘들로 자신과 타인에 대한 인지적 사고가 가능해야 적절히 이해하
고 표현할 수 있다(Montgomery, 2002). 그리고 이러한 심성동사는 지각동사(perception verbs), 인지동사(cognition verbs)와 심리동 사(psychological verbs)로 구분된다(Lee, 2004; Quirk, 1985). 이러 한 심성동사의 3 가지 유형 지각, 인지, 심리 심성동사를 자세히 살펴 보면 다음과같다.

지각동사(psychological verbs)는 일반 행위동사나 상태동사와 달리, 인간의 감각기관 중 시각, 청각, 촉각, 미각, 후각의 5 가지 주요 감각계를 통하여 사물, 상황, 변화 등을 인식하여 아는 일을 나타낸 다. 지각동사에 대해서는 통사론적으로나 의미론적 관점에서, 다 양한 언어를 대상으로 많은 학자들(Baker, 1999; Evans \& Wilkins, 
Table 1. Basic structure of perceptual verbs

\begin{tabular}{lccc}
\hline \multirow{2}{*}{ Sense modality } & \multicolumn{3}{c}{ Dynamic system } \\
\cline { 2 - 4 } & Activity & Experience & Copulative \\
\hline Sight & Look at & See & Look \\
Hearing & Listen to & Hear & Sound \\
Touch & Feel & Feel & Feel \\
Taste & Taste & Taste & Taste \\
Smell & Smell & Smell & Smell \\
\hline
\end{tabular}

Source from Viberg (1983).

2000; Felser, 1998; Safir, 1993; Viberg, 1983)이 활발한 연구활동을 하고 있다. 특정 지각 부문은 보기, 듣기, 접촉, 맛, 냄새의 오감 형식 (five sense modalities)으로 나누고, 일반 부문은 활동(activity), 경 험(experience), 연계(copulative)의 3 부문으로 나누어 15 가지의 지 각동사의 기본 틀을 Table 1 과 같이 제시하였다.

인지(cognition)란 용어는 철학이나 심리학, 심리언어학, 인공지 능 등에서 널리 사용되어 뚜렷한 개념 규정 없이 지각(perception) 과의 상호관계를 통해서 이해되거나 넓은 의미로 '이해와 기억을 통한 지식의 습득과 문제 해결'의 전 영역에 걸쳐 이해되고 있다. 인 지란 기억 속에서 있는 정보의 종류와 그러한 정보를 획득하고 활 용하는 과정을 말하는 것으로, 곧 지각하고, 알고, 기억하며, 추리 하고, 사유하는 활동이다(Byun, 2002). 즉, 인지는 심리적인 정신 활동의 영역이라는 것이며, ‘앎’을 기준으로 하여 감각이나 지각의 개념을 포함한다. 즉 인지동사는 외부대상에 대한 감각자극을 통 해 객관적으로 지각하고 구체적 표현을 통해 주관적으로 개념화하 는 과정이 포함되는 동사이다. 인지동사(cognition verbs)는 지각 차원의 정신작용에 의한 언어화 과정 이후의 과정을 언어화한 것 으로 인간이 경험세계 속의 경험과 인식을 받아들이고 내면화하 는 정신적/심리적 과정이다. 이때 이러한 인지과정을 나타내는 동 사류가 인지동사인 것이다. 인지동사는 인간이 심리적으로 받아들 이는 일련의 사태 파악이나 사물에 대한 인식 등에 대하여 이를 언 어로 표현하는 언어형식이다(Byun, 2002).

심리동사란 화자의 내면적 심리상태를 표현한 동사로 감정동사 라고도 하며, 다른 동사 부류와는 상이한 통사적/의미적 특성을 보 이는 경우가 많다. 즉, 심리동사는 단어의 의미가 단독으로 정서적 의미를 갖고 사용되기도 하지만 이보다는 문장구조 내에서 다양하 게 해석될 수 있다는 특성이 있다(Kim, 2004). 특히 심리동사는 화 자의 '주관적 감정'을 표현하는 어휘로 인간이 경험하는 '감정'과 직 접적인 관련을 맺는다(Kim, 2004; Kim, 2009; Kim, Kim, Park, Oh, \& Chung, 1998). Kim (2004)에 의하면 ‘슬프다’라는 동사의 의 미를 알기 위해서는 '슬픔'이라는 감정이 무엇인지를 알아야 하고
'기쁘다'라는 동사의 의미를 알기 위해서는 '기쁨'이라는 감정이 무 엇인지를 알아야 한다. '감정동사'의 의미를 알기 위해서는, 해당하 는 '감정'의 의미를 먼저 알아야 한다. 이는 모든 감정동사에서 마찬 가지이다. 이러한 심리동사는 '주관동사, 감정동사, 정서형용사, 개 인동사, 심리형용사, 주관형용사, 자기판단동사, 느낌동사' 등으로 혼용되고 있고 그 범주의 큰 틀은 주관적 심리상태를 나타내는 술 어라는 점에서는 공통적이지만, 세부적으로는 명확한 정의도 없이 쓰이거나 논의에 따라서 동사와 형용사를 포괄하기도 하고, 동사 나 형용사만을 지칭하는 의미로 쓰이기도 한다(Kim, 2009).

현재까지 심성동사 어휘 발달연구는 첫째, 심성동사 어휘의 출현 과 관련된 연구와 둘째, 심성동사 어휘의 습득 발달과 관련된 요인 들을 살펴보는 것과 같은 2 가지 주제로 연구가 주로 진행되었다 (Lee, 2011; Lee \& Kim, 2011a, 2011b).

심성동사 어휘의 출현과 관련된 연구들을 살펴보면, 5 세 이하의 어린 아동들을 대상으로는 아동이 어떻게 심성어휘를 습득하는지 에 대한 연구가 주로 진행되었다. Bretherton과 Beeghly (1982)는 1-2세 유아들을 둔 어머니들에게, 유아가 자신의 마음을 표현하는 방법으로는 어떠한 것들이 있는지를 살펴보고 관찰 내용을 기술하 도록 하였다. 그리고 Shatz, Wellman과 Silber (1983)는 발화가 가 능한 2-4세 아동들이 어떠한 심성동사를 먼저 습득하여 산출하는 지를 부모관찰을 통해 살펴보았다. 연구결과 어린 아동들은 알다 (know), 생각하다(think), 그리고 기억하다(remember)와 같은 심 성동사 어휘들을 먼저 습득하여 사용하고 있었다. 그리고 Moore, Bryant와 Furrow (1989), Nguyen과 Frye (1999), Johnson과 Well$\operatorname{man}$ (1980)은 3-5세 아동들을 대상으로 심성어휘(mental terms) 중 구체적인 어휘(desire)와 비구체적인 어휘(think)를 구분하여 어 떠한 심성어휘가 먼저 발달하는지를 살펴보았다. 연구결과 아동들 은 이들 어휘들을 구분하여 이해하고는 있지만 잘 구분하여 사용 하지는 못하였으며 비구체적인 어휘보다는 구체적 어휘를 더 먼저 사용하였다. 학령기 아동들을 대상으로는 심성동사(mental verbs) 의 구조화 발달 시기에 대한 연구가 주로 진행되었다(Schwanenflugel, Fabricius, \& Noyes, 1996; Schwanenflugel, Henderson, \& Fabricius, 1998). 즉 심성동사 어휘에 대한 내적 구조화가 일반성인 과 유사해지는 연령 시기에 대한 것으로 연구결과 7-8세 일반아동 들의 심성동사 내적 구조화는 일반성인과 유사하였다.

심성동사 어휘 발달과 관련된 요인에 대한 연구 중 일반아동들 을 대상으로 한 연구 주제는 (1) 어머니의 심리상태(Ruffman, Slade, \& Crowe, 2002), (2) 가족 내의 심성어휘 사용정도(Jenkins, Turrell, Kogushi, Lollis, \& Ross, 2003), (3) 이야기책을 잘 읽어주는 환경 (Dyer-Seymour, Shatz, Wellman, \& Saito, 2004; Dyer, Shatz, \& 
Wellman, 2000), (4) 어머니의 인식론적 복잡성(Hutchins, Bond, Silliman, \& Bryant, 2009) 등이 있으며 연구결과 이와 같은 네 가지 요인들은 아동의 심성동사 어휘 발달에 유의미하게 영향을 미치는 것으로 나타났다. 또한 언어장애아동들을 대상으로 한 심성동사 어휘 연구들을 살펴보면, Spanoudis, Natsopoulos와 Panayiotou (2007)는 언어장애가 있는 아동들의 심성동사 이해 정도를 일반아 동과 비교하였다. 연구결과 이들 언어장애 아동들은 일반아동들 에 비하여 심성동사 측정(mental verb measures) 점수와 화용언어 평가도구 점수가 일반아동들보다 낮았다. 즉, 화용언어에 문제를 보이는 언어장애 대상자들은 심성동사 어휘에 대한 이해 정도가 낮았다. 또한 6-9세 윌리엄스증후군(Williams syndrome) 장애아 동들은 수동태 심성동사(psychological verbs)에 대한 이해 정확도 가 일반아동들에 비해 유의미하게 많이 떨어졌다(Perovic \& Wexler, 2010).

이상의 심성동사 어휘와 관련된 이전 연구들을 살펴본 결과, 심 성동사는 아동의 의사소통 및 언어발달, 그리고 화용언어능력과 관련이 있음을 확인하였다. 하지만 아직까지 일반아동들을 대상으 로 심성동사 사용률과 화용언어능력 간의 직접적인 관련성을 살펴 본 연구는 없었다. 이에 일반아동 집단을 대상으로 이야기과제에 서의 심성동사 사용률과 아동화용언어체크리스트의 점수 간에 관 련이 있는지를 살펴보았다. 구체적 연구문제는 다음과 같다.

1) 22 명 일반아동 집단에서 연령, 지능, 수용 및 표현어휘능력점 수, 이야기과제에서의 이야기이해점수, 심성동사 사용률, 발화 문장의 복잡성 정도에 따른 심성동사의 사용률, 아동화용언 어체크리스트 하위영역별 점수간의 관련성이 있는가?

2) 심성동사사용률이 화용언어능력을 설명해 줄 수 있는 설명모 형은 가능한가?

\section{연구방법}

\section{연구 참여자}

본 연구의 참여자는 심성동사 어휘에 대한 발달이 충분히 이루 어진 시기로 알려진(Schwanenflugel et al., 1998) 만 6세부터 9세까 지의 일반가정 아동들로 서울 및 경기지역 아동 22 명(남 7 명, 여 15 명)을 대상으로 한국 웩슬러 유아지능검사(Korean-Wechsler Preschool and Primary Scale of Intelligence, K-WPPSI; Park, Kwak, \& Park, 1997)와 한국 웩슬러 아동지능검사-III (Korean-Wechsler Intelligence Scale for Children, K-WISK-III; Kwak, Park, \& Kim, 2001)에서 동작성 지능 지수가 85 이상(-1 SD 이내)이고 수용 및 표 현어휘력검사(Receptive \& Expressive Vocabulary Test, REVT;
Table 2. Standard of participant selection and group characteristics

\begin{tabular}{lc}
\hline Characteristic & TD (N=22) \\
\hline Age $(\mathrm{mo})$ & $93.3 \pm 10.0$ \\
Sex & 7 \\
Male & 15 \\
Female & \\
REVT & $91.1 \pm 13.9^{\mathrm{a})}$ \\
$\quad$ Receptive & $90.9 \pm 13.9^{\mathrm{a})}$ \\
Expressive & $110.6 \pm 7.9^{\mathrm{b})}$ \\
K-WISC-III (K-WPPSI) &
\end{tabular}

Values are presented as mean \pm SD.

$\mathrm{TD}=$ typical development; REVT = Receptive and Expressive Vocabulary Test (Kim, Hong, Kim, Jang, \& Lee, 2009); K-WPPSI = Korean-Wechsler Preschool and Primary Scale of Intelligence (Park, Kwak, \& Park, 2002); K-WISC-III=Korean-Wechsler Intelligence Scale for Children-III (Kwak, Park, \& Kim, 2001).

${ }^{a}$ Greater than -1 SD, b) greater than 85 scores.

Kim, Hong, Kim, Jang, \& Lee, 2009) 결과 수용 및 표현어휘점수 모 두가 REVT 등가연령 기준점수에서 -1 SD 이상의 수행을 보이는 아동들만을 대상으로 하였다(Table 2).

모집방법은 개인적 친분이 있는 지인들의 소개를 통해 서울 및 경기도에 소재하는 개인가정이나 어린이집, 공부방을 소개받고 방 문하여 연구목적과 진행절차를 설명한 후, 연구대상 조건에 해당 하는 22 명의 아동들을 대상으로 우선 지능검사와 어휘검사를 실 시하였다.

\section{연구 과제}

이야기 다시말하기

“이야기 다시말하기(story retelling)"에서 사용될 “개구리 이야 기(Frog, Where Are You?; Mayer, 1969)"는 글자 없는 그림책으로, The Strong Narrative Assessment Procedure (Strong, 1998)와 같 은 이야기평가 과제도구에 포함된 네 가지 글자 없는 그림책 중 한 권으로 중학생 이하 일반대상자들과 다양한 언어장애를 보이는 아동들을 대상으로 이야기능력(narrative skills)을 평가하는 과제 로 많이 사용되어 왔다( $\mathrm{Ku}, 2008$; Yang, 2000).

이야기의 내용은 주인공 소년이 강아지와 함께 사라진 자신의 애완용 개구리를 찾아 나서면서 발생하는 문제들을 그리고 있다. 즉, 소년이 문제(애완용 개구리가 어느 날 갑자기 사라짐)를 해결해 가는 과정에서 벌어지는 사건에 대한 이야기 그림 장면을 보면서 등장인물들의 생각과 감정을 읽고 표현할 수 있어야 한다. 이러한 마음(심성) 읽기 과정이 포함된다는 점에서 "개구리 이야기” 그림 책을 보고 "이야기 다시말하기” 과제는 심성동사 어휘표현 분석에 적절하다고 생각되어 연구의 과제로 선정하였다(Appendixes 1,2). 


\section{아동화용언어체크리스트(CPLC)}

아동의 화용언어능력을 측정하기 위하여 '아동화용언어체크리 스트(Children's Pragmatic Language Checklist, CPLC; Oh, Lee, \& $\mathrm{Kim}, 2012)^{\prime}$ 를 사용하였다. CPLC는 국내외 화용언어 검사도구를 분석하여 국내에 적합한 문항만을 선정하고 수정하여 4 개(담화관 리, 상황.청자.맥락 조건에 따른 조절 및 적용능력, 의사소통 의도, 비언어적 의사소통)의 하위영역으로 구분된 체크리스트이다.

아동화용언어체크리스트는 44 문항으로 구성되어 있으며, 양육 자나 아동을 잘 아는 성인이 아동의 일상생활에서의 화용능력을 각 문항별 4점 척도(0-3점)로 응답하도록 되어 있다. 현재 예비연구 를 통해 내적타당도와 신뢰도가 입증되었으며 현재 표준화 과정 중 에 있으며, 비교적 짧은 시간 내(15분 내외)에 아동의 화용수행 정 도를 알아볼 수 있다(Oh et al., 2012; Oh, 2018). 아동화용언어체크 리스트는 담화관리(discourse management, DM; 9문항), 상황에 따른 조절 및 적용능력(contextual variation, CV; 15 문항), 의사소 통 의도(communication intent, CI; 12 문항), 비언어적 의사소통 (nonverbal communication, NC; 8 문항)의 4 개 하위영역별로 구분 되어 있다.

\section{연구절차}

연구는 아동의 집에 개별적으로 두 번씩 방문하였으며, 실험은 총 세 단계로 실시되었다. 첫 번째 방문 때 실시한 1 단계는 사전 검 사단계로 동작성지능검사(K-WPPSI, K-WISC-III)와 수용-표현어 휘력검사(REVT)를 이용하여 정상아동 22명을 선발하였다. 동작 성 지능검사와 어휘검사는 모두 개별로 실시되었다. 그리고 검사자 가 대상아동과 사전검사를 실시할 동안 어머님께 아동화용언어체 크리스트(CPLC)를 드려 작성할 수 있도록 하였다. 아동과의 1 단계 실험이 끝난 뒤 대상 아동의 어머니가 작성한 체크리스트 내용을 확인하여 정확하게 작성하였는지 살펴보고, 기입이 잘못되어 있거 나 빠진 부분은 실험자가 다시 어머니(주양육자)에게 질문하여 작 성하도록 하였다.

두 번째 방문 2 단계 검사는 1단계 실험이 끝나고 일주일 뒤에 이 루어졌다. 2단계 ‘이야기 다시말하기’ 검사 단계에서는 준비된 글자 없는 그림 이야기 책(Mayer, 1969)에 대한 다시말하기를 통해 자연 스런 아동의 이야기 발화 속에 심성동사를 사용한 문장 표현을 기 록하는 방법으로 아동의 발화내용을 녹화하여 이후에 발화내용 을 전사하여 심성동사 사용률과 문장의 복잡성 단계별 사용률을 측정하였다. ‘이야기 다시말하기' 검사는 약 20 분 정도가 소요되었 다. 자세한 절차는 다음과 같다.

먼저 이야기에 대한 소개를 해 주면서 이후 아동이 다른 아동에
게 이야기 해 줄 수 있어야 한다고 설명하였다. 그리고 글자 없는 이 야기 그림책의 내용을 대상자에게 그림을 보여주면서 이야기를 들 려주었다. 이야기 종료 후 연구자는 이야기와 관련된 사실적 정보 이해 5 문제와 추론이해 5 문제, 총 10 문제를 대상아동에게 묻고 준 비된 응답지에 아동의 발화내용을 체크하거나 응답지에 적절한 대 상자 발화목록이 없을 경우에는 응답지에 받아 적었다. 이후 아동 스스로 그림을 보면서 이야기를 다시 해 보도록 유도하였다. 그리 고 아동의 모든 발화내용은 비디오카메라(Olympus fe-230)를 이 용해 녹화하였다. 이후 연구실에서 아동이 발화한 이야기의 녹음 내용을 전사하였다. 전사한 내용 중에 아동이 발화한 심성동사 어 휘의 빈도와 심성동사 어휘 사용 발화문장의 복잡성을 4 가지 단계 로 구분하여 측정하였다.

이야기 그림책은 총 24 개의 장면으로 구성되어 있으며, 아동발 화 녹화시간은 평균 7분 정도 소요되었다. 위의 전체적인 연구절차 는 아래와같은 지시사항이 포함된 세부적 절차에 의해 진행되었다. 연구참여대상자 아동에게 먼저 그림책을 보여주며 다음과 같은 지시사항을 전달하였다. "선생님이 그림을 보여주면서 이야기를 들 려줄 건데 잘 듣고 나서 이따가 그 내용을 똑같이 다시 이야기 해 주 어야 해. $\bigcirc \bigcirc$ 이가 이야기하는 것을 여기에 녹음해서 친구들한테 들려줄 거거든, 그러니까 잘 들어야 해. 들어봐." 그리고 글자 없는 그림책인 '개구리 이야기' 그림을 한 장씩 직접 대상 아동에게 보여 주면서 미리 준비된 이야기 글을 연구자가 직접 들려주었다(Pae, Kwon, \& Jin, 2018). 이야기를 마치고 아동에게 이해문제를 제시하 여 아동의 반응을 기록한 후, 아동에게 조금 전에 들려준 이야기 내용을 그림책을 보면서 다시 이야기 해달라고 하였다: “ $\bigcirc \bigcirc$ 이가 이야기한 내용을 여기에 녹음해서 다른 친구들에게 들려주자. 조 금 전에 들은 내용을 이 그림을 보면서 다시 잘 이야기해 줘.”라고 말하고 아동이 직접 이야기책을 넘기면서 말하거나 아동의 반응에 따라 평가자가 이야기책을 넘겨주었다.

\section{평가자 간 신뢰도}

본 연구에 사용된 2가지 연구과제 중 이야기 다시말하기 과제의 실험 진행과 채점은 연구자가 직접 실시하였다. 그리고 아동이 표현 한 이야기 내용은 언어치료사 1 급 자격증이 있는 석사 이상의 언어 치료사가 전사를 하였다. 그리고 전사를 시작할 때, 수집된 "이야 기 다시말하기" 동영상의 $30 \%$ 가 1 급 언어치료사에 2 인에 의해 $98 \%$ 이상의 내용 일치를 보였다. 또한 이야기의 이해 문제에 대한 연구참여대상자의 응답내용 중 정오판단 항목에 정확히 포함되지 않는 애매한 내용 모두는 위의 2 인의 언어치료사의 동의에 의해 정 오를 판단하도록 하였다. 


\section{자료 분석 및 통계처리}

아동의 이야기 발화내용은 대상 아동의 ‘이야기 다시말하기’ 비 디오 영상 화면내용을 보면서 전사하였다. 이후 전사한 내용은 Cunit 단위로 구분하였다. 그리고 아동의 이야기 다시말하기 과제에 서 심성동사 유형별 사용률을 측정하였다. 즉, 아동의 전체 발화에 서 심성동사 유형별 사용빈도를 전체 발화문장 절(clause)의 수로 나누어 계산하였다(Table 3).

이후 이러한 심성동사 어휘가 사용된 문장은 Baumgartner, Biagini와 Devescovi (1998)의 연구에 제시되어 있는 발화문장의 복 잡성 4단계(I-IV)를 참고로 하여 인지, 심리, 지각 심성동사 표현문 장의 복잡성을 4 단계로 구분하여 분석하였다. 그리고 이렇게 분석 된 세 가지 심성동사 복잡성 단계별 심성동사 사용빈도를 전체 발 화문장수로 나누어 복잡성 단계별 사용률을 계산하였다(Table 4).

또한 이야기 이해문제에 대한 대상자의 응답내용을 기록하여 2 명 언어치료사의 동의하에 정오를 판단하고, 사실이해와 추론이해 각각 5점 만점 기준으로 채점하였다.

IBM SPSS version 21.0 프로그램을 이용하여, 일반가정아동들 (22명)의 ‘이야기 다시말하기’ 과제에서의 이야기이해점수, 심성동

Table 3. A method of calculating the usage rate by type of mental verb in story retelling task

\begin{tabular}{|c|c|}
\hline & Calculation by classification of mental verbs \\
\hline Cognitive & $\begin{array}{l}\text { Frequency of cognitive verbs utterance (A) / Total number of } \\
\text { utterance clauses }\end{array}$ \\
\hline Psychological & $\begin{array}{l}\text { Frequency of psychological verbs utterance (B) / Total number of } \\
\text { utterance clauses }\end{array}$ \\
\hline Perceptive & $\begin{array}{l}\text { Frequency of perceptive verbs utterance (C) / Total number of } \\
\text { utterance clauses }\end{array}$ \\
\hline Mental verb & $A+B+C /$ Total number of utterance sentences \\
\hline
\end{tabular}

사 유형별 사용률 및 이야기 발화문장 복잡성 단계별 심성동사 사 용률과 CPLC 4가지 하위영역별 점수 간의 관련성을 Pearson 적률 상관분석(Pearson product-moment correlation analysis)을 통해 살펴보았다. 그리고 위의 상관 연구결과를 통해 유의미한 상관을 보이는 변수들을 통해 화용언어능력 점수를 예측해 줄 수 있는 설 명모형이 가능한지를 회귀분석(regression analysis)을 통해 살펴보 았다.

\section{연구결과}

\section{연령, 지능, 수용 및 표현어휘능력점수, 이야기 사실 및 추론이해점수, 심성동사 유형별 사용률, 이야기 발화문장 복잡성 단계별 심성동사 사용률, 그리고 CPLC 하위영역 (DM, CV, Cl, $\mathrm{NC}$ )과의 상관}

일반아동들의 연령, 지능, 어휘능력, ‘이야기 다시말하기' 과제에 서의 이야기 이해점수, 심성동사 유형별 사용률, 이야기 발화문장 복잡성 단계별 심성동사 사용률과 CPLC 하위영역에 대한 기술통 계값과 이들 변수 간의 상관을 살펴본 결과는 Tables 5, 6과 같다.

연구결과, 연령은 수용 및 표현어휘능력점수 $(r=.43, r=.57)$, 이 야기 추론이해점수 $(r=.51)$, 그리고 문장의 복잡성 I단계 $(r=.56)$ 와 관련이 있는 것으로 나타났다. IQ점수는 CPLC 하위영역 중 의사 소통 의도 $(\mathrm{CI})$ 점수와만 유의미한 상관을 보였다 $(r=.50)$. 수용어 휘능력점수는 표현어휘능력점수와만 유의미한 상관을 보였으나 $(r=.45)$, 표현어휘능력점수는 이야기 추론이해 $(r=.47)$ 및 총점 $(r=.44), \mathrm{CPLC}$ 하위영역 중 의사소통 의도 $(r=.46)$ 와 비언어적 의 사소통 $(\mathrm{NC} ; r=.47)$ 영역점수와 유의미한 상관을 보였다. 그리고 인 지심성동사사용률 $(r=-.49)$ 과는 부적 상관을 보였다.

Table 4. Four complexity levels of mental verbs attribution in the stories

\begin{tabular}{|c|c|}
\hline & Description \\
\hline Level I & $\begin{array}{l}\text { A predicate and one argument } \\
\text { The narrator produces a comment on the character's internal state } \\
\text { The attribution establishes only a relationship between the narrator (who produces the attribution) and the character (Who experiences the internal state) } \\
\text { e.g., "he's afraid" or "he thinks" }\end{array}$ \\
\hline Level II & $\begin{array}{l}\text { A predicate and two or more arguments } \\
\text { The narrator establishes a relationship with the character and his world } \\
\text { e.g., "he is afraid of the owl" }\end{array}$ \\
\hline Level III & $\begin{array}{l}\text { First-order recursion } \\
\text { As on level B, the narrator establishes a relationship with the character and his world, but this relationship is expressed by two predicates } \\
\text { e.g., "the child wants to find the frog" }\end{array}$ \\
\hline Level IV & $\begin{array}{l}\text { Second-order recursion } \\
\text { Two structures of predicate and argument related to each other } \\
\text { e.g., "he was afraid that it would fall, he think that the frog has escaped" }\end{array}$ \\
\hline
\end{tabular}

Example sentences from Baumgartner, Biagini, \& Devescovi (1998). 
Table 5. Results of story comprehension origin score, MV rate, MV rate for sentence complexity step, and CPLC ( $\mathrm{N}=22)$

\begin{tabular}{ll}
\hline & Value \\
\hline Group characteristics & $93.3 \pm 10.0(79-112)$ \\
Age (mo) & $110.6 \pm 7.9(95-126)$ \\
IO & $91.1 \pm 13.9(67-115)$ \\
Receptive & $90.9 \pm 13.9(70-123)$ \\
Expressive & \\
Comprehension & $4.7 \pm 1.3(3-5)$ \\
Comprehension of the facts & $3.1 \pm 1.3(0-5)$ \\
Inference & $7.7 \pm 1.7(4-10)$ \\
Total & \\
MV rate & $0.08 \pm 0.06(0.00-0.29)$ \\
Cognitive mental verb & $0.03 \pm 0.02(0.00-0.08)$ \\
Psychological mental verbs & $0.15 \pm 0.08(0.03-0.41)$ \\
Perceptive mental verbs & \\
MV rate for sentence complexity step & $0.16 \pm 0.07(0.03-0.41)$ \\
I & $0.24 \pm 0.06(0.12-0.35)$ \\
II & $0.05 \pm 0.04(0.00-0.15)$ \\
III & $0.20 \pm 0.10(0.03-0.48)$ \\
IV & \\
CPLC & $20.3 \pm 3.7(16-27)$ \\
Discourse management & $33.0 \pm 5.5(23-45)$ \\
Contextual variation & $25.1 \pm 4.6(14-36)$ \\
Communication intent & $17.5 \pm 2.8(14-23)$ \\
Nonverbal communication & $96.0 \pm 14.9(67-131)$ \\
Total & \\
\hline & \\
\hline &
\end{tabular}

Values are presented as mean $\pm S D$ (min-max).

$\mathrm{MV}=$ mental verb; $\mathrm{CPLC}=$ Children's Pragmatic Language Communication.

이야기 사실이해점수는 문장의 복잡성 III단계와 상관을 보였으 며 $(r=-.54)$, 추론이해점수는 이해종합점수 $(r=.75)$, 인지동사 사용 률 $(r=-.63)$ 과 관련이 있음을 확인하였다. 그리고 이해종합점수는 인지동사 사용률 $(r=-.53)$ 과 인지동사 사용률은 문장의 복잡성 IV 단계 $(r=.61)$ 와 심리동사 사용률은 CPLC의 하위영역인 상황에 따 른 조절 및 적용능력 $(\mathrm{CV} ; r=.45)$ 과 관련이 있는 것으로 나타났다. 그리고 지각동사 사용률은 문장의 복잡성 III단계 $(r=.43)$ 와 IV단 계 $(r=.58)$ 와 관련이 있는 것으로 나타났다.

그리고 화용언어체크리스트의 하위영역들은 서로 간에 상관이 높게 나타났다. 또한 $p<.05$ 수준에서는 유의미하게 해석할 수는 없 지만 $p<.10$ 수준에서 심성동사 사용률은 의사소통 의도 $(r=.41$, $p<.056)$ 와 CPLC 총점 $(r=.40, p<.065)$ 과 관련이 있는 것으로 보여 지며, 비언어적 의사소통 $(r=.33, p<.140)$ 과의 관련성은 유의미하지 않은 것으로 나타났다. 그리고 지각동사 사용률은 담화관리 $(\mathrm{DM}$; $r=.37, p<.094)$ 와어느 정도 관련이 있는 것으로 해석할수 있다.

위의 결과를 종합해 보면, 이야기 이해점수는 발화 문장의 복잡

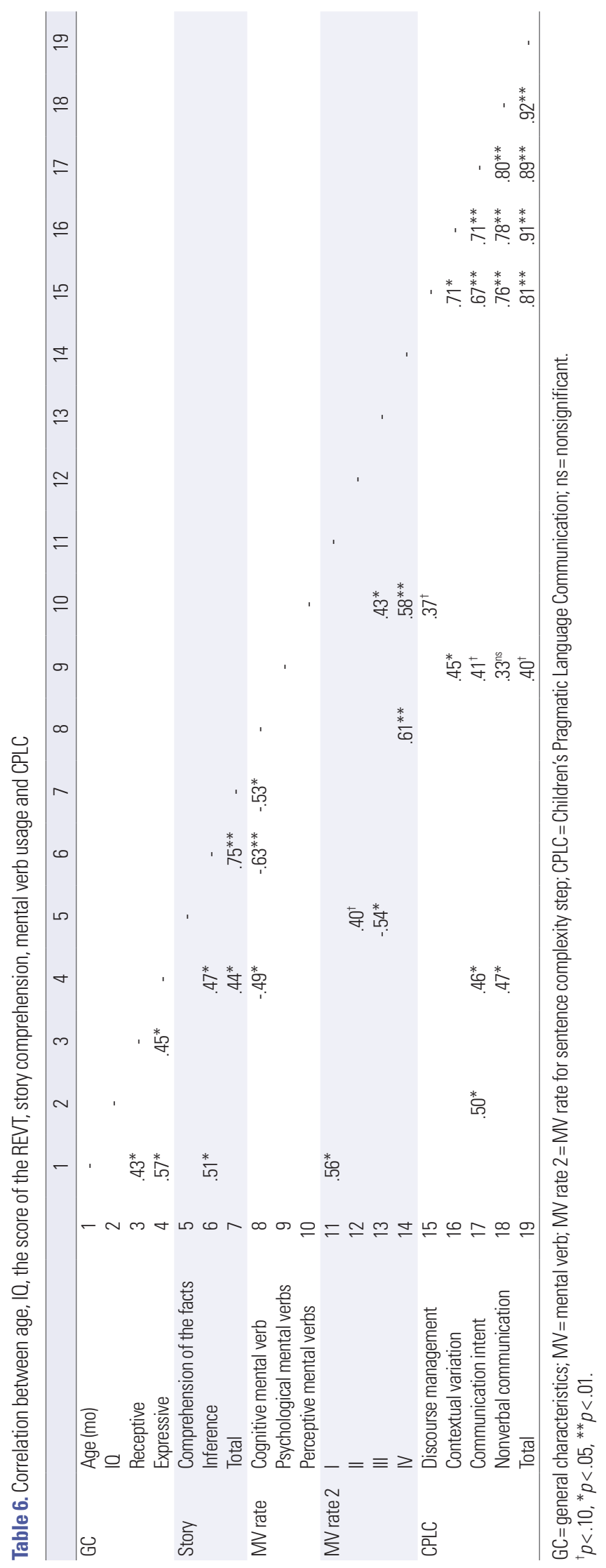

http://www.e-csd.org 
성 III, IV단계와 인지동사 사용률과 관련이 있으며, 지능과 표현어 휘능력점수, 그리고 심리동사와 지각동사 사용률은 CPLC 점수와 관련이 있는 것으로 나타났다. 특히, 심리동사 사용률은 CPLC의 하위영역 중 상황에 따른 조절능력(CV)과 의사소통 의도(CI), 아 동화용언어체크리스트총점(CPLC total)과 관련이 있었다. 그리고 지각동사 사용률은 담화관리영역 $(\mathrm{DM})$ 과 어느 정도 관련이 있는 것으로 나타났다 $(r=.37, p<.094)$.

\section{심성동사 사용률과 화용언어능력 점수와의 관련성}

상관분석 결과, 지능, 표현어휘능력점수, 그리고 심성동사 중 심 리동사와 지각동사 사용률은 CPLC 점수와 관련이 있는 것으로 나 타났다. 구체적으로 살펴보면 심리동사사용률은 CPLC의 하위영역 중 상황에 따른 조절능력 $(\mathrm{CV} ; r=.45)$ 과, 의사소통 의도 $(\mathrm{CI} ; r=.41$, $p<.056$ ) 그리고 아동화용언어체크리스트 총점(CPLC total; $r=.40$, $p<.065)$ 과 관련이 있었으며 지각동사 사용률은 담화관리(DM; $r=.37, p<.094)$ 영역과 어느 정도 관련이 있는 것으로 나타났다.

아동 개인특성을 나타내는 변수인 IQ점수는 의사소통 의도(CI; $r=.50)$ 와 유의미한 상관을 보였으며, 표현어휘 능력점수는 의사소 통 의도(CI; $r=.46)$ 와 비언어적 의사소통(NC; $r=.47)$ 과 유의미한 상관결과를 보였다. 이에 아동화용언어체크리스트 점수들을 종속 변인으로 하고 지능, 표현어휘능력점수, 그리고 인지, 심리, 지각 심 성동사사용률을 독립변수로 하여 단계적 회귀분석을 진행하였다.

의사소통 의도 $(\mathrm{CI})$ 와 유의미한 상관을 보인 변수인 IQ점수와 표

Table 7. Simple regression analysis result for $\mathrm{Cl}$ score ( $\mathrm{N}=22)$

\begin{tabular}{|c|c|c|c|c|c|}
\hline & \multicolumn{2}{|c|}{ Unstandardized coefficients } & \multirow{2}{*}{$\begin{array}{c}\text { Standardized } \\
\text { coefficients }\end{array}$} & \multirow{2}{*}{$t$} & \multirow{2}{*}{ Sig. } \\
\hline & B & SE & & & \\
\hline 10 & .293 & .113 & .50 & 2.583 & .018 \\
\hline & \multicolumn{5}{|c|}{$\mathrm{R}=.50, \mathrm{R}^{2}=.25\left(\right.$ adjusted $\mathrm{R}^{2}=.213$ ), $F=6.671, p=.018$} \\
\hline
\end{tabular}

$\mathrm{Cl}=$ communication intent.

Table 8. Estimated regression model of the relationship between $\mathrm{Cl}$ score and the 10

$$
\text { Cl score }=-7.23+.29(10)
$$

$\mathrm{Cl}=$ communication intent.

Table 9. Simple regression analysis result for NC score ( $N=22)$

\begin{tabular}{|c|c|c|c|c|c|}
\hline & \multicolumn{2}{|c|}{ Unstandardized coefficients } & \multirow{2}{*}{$\begin{array}{l}\text { Standardized } \\
\text { coefficients }\end{array}$} & \multirow{2}{*}{$t$} & \multirow{2}{*}{ Sig. } \\
\hline & B & SE & & & \\
\hline \multirow[t]{2}{*}{10} & .094 & .039 & .47 & 2.382 & .027 \\
\hline & \multicolumn{5}{|c|}{$\mathrm{R}=.47, \mathrm{R}^{2}=.22$ (adjusted $\mathrm{R}^{2}=.182$ ), $F=5.675, p=.027$} \\
\hline
\end{tabular}

$\mathrm{NC}=$ nonverbal communication.
현어휘능력점수 두 개의 독립변수로 의사소통 의도(CI) 점수를 측 정하는 모형에 대한 통계적 유의성 검정결과, 표현어휘능력점수는 유의하지 않아 제외하였고 IQ점수만이 CPLC의 의사소통 의도 $(\mathrm{CI})$ 를 예측하는 변수로서 설명모형이 가능하였다 $(F=6.67, p=.018)$ (Table 7). IQ점수는 유의수준 .05에서 의사소통 의도(CI) 점수를 유의하게 설명하고 있으며 $(t=2.583, p=.018)$, 의사소통 의도(CI) 총 변화량의 $25 \%$ (수정결정계수에 의하면 21\%)가 IQ점수에 의해 설명되고 있었다. 의사소통 의도 점수와 IQ점수와의 관계를 나타 내는 회귀선의 식을 추정한 결과는 Table 8과 같다.

비언어적 의사소통 $(\mathrm{NC})$ 과 유의미한 상관을 보인 표현어휘능력 점수는 비언어적 의사소통 $(\mathrm{NC})$ 점수를 예측하는 변수로서 설명모 형이 가능하였다 $(F=5.68, p=.027$ ) (Table 9). 표현어휘능력점수는 유의수준 .05 에서 비언어적 의사소통 $(\mathrm{NC})$ 점수를 유의하게 설명하 고 있으며 $(t=2.382, p=.027$ ), 의사소통 의도 총 변화량의 $22 \%$ (수 정결정계수에 의하면 $18 \%$ )가 IQ점수에 의해 설명되고 있었다. 의 사소통 의도 점수와 IQ점수와의 관계를 나타내는 회귀선의 식을 추정한 결과는 Table 10과 같다.

그리고 심리동사 사용률은 화용언어능력 중 상황에 따른 조절 능력점수 $(\mathrm{CV})$ 를 예측하는 변수로서 설명모형이 가능하였다(Tables 11, 12). 심리동사 사용률 점수의 상황에 따른 조절능력점수 $(\mathrm{CV})$ 에 대한 기여도와 통계적 유의성을 검정한 결과, $F$ 통계값은 5.12 , 유의확률은 .035 로 심리동사 사용률점수는 유의수준 .05에 서 상황에 따른 조절능력점수 $(\mathrm{CV})$ 를 유의하게 설명하고 있으며

Table 10. Estimated regression model of the relationship between NC score and the REVT-E

$$
\text { NC score }=8.951+.094 \text { (REVT-E) }
$$

$\mathrm{NC}=$ nonverbal communication; REVT-R=Receptive \& Expressive Vocabulary Testreceptive vocabulary.

Table 11. Estimated regression model of the relationship between CV score and the psychological MV usage rate score

$$
\text { CV score }=30.6+88.16 \text { (usage rate of psychological mental verbs) }
$$

$\mathrm{CV}=$ contextual variation; $\mathrm{MV}=$ mental verb.

Table 12. Simple regression analysis result for CV score ( $\mathrm{N}=22)$

\begin{tabular}{lccccc}
\hline & \multicolumn{2}{c}{$\begin{array}{c}\text { Unstandardized } \\
\text { coefficients }\end{array}$} & $\begin{array}{c}\text { Standardized } \\
\text { coefficients }\end{array}$ & $t$ & Sig. \\
\cline { 2 - 5 } & $\mathrm{B}$ & $\mathrm{SE}$ & & & \\
\hline $\begin{array}{c}\text { Psychological } \\
\text { mental verbs }\end{array}$ & $\begin{array}{c}88.161 \\
\left.\mathrm{R}=.45, \mathrm{R}^{2}=.21 \text { (adjusted } \mathrm{R}^{2}=.16\right), F=5.12, p=.035\end{array}$ & \\
\hline
\end{tabular}

$\mathrm{CV}=$ contextual variation 
$(t=2.26, p<.035)$, 상황에 따른 조절능력점수 $(\mathrm{CV})$ 총 변화량의 $21 \%$ (수정결정계수에 의하면 $16 \%$ )가 심리동사 사용률에 의해 설 명되고 있었다.

상황에 따른 조절능력점수 $(\mathrm{CV})$ 와 심리동사 사용률점수의 관계 를 나타내는 회귀선의 식을 추정한 결과는 Table 11과 같다.

\section{논의 및 결론}

연령은 수용 및 표현어휘능력점수 $(r=.43, r=.57)$, 이야기 추론 이해점수 $(r=.51)$, 그리고 문장의 복잡성 I단계 $(r=.56)$ 와 관련이 있 는 것으로 나타났다. 즉 연령의 증가는 어휘능력 향상과 관련이 있 으며 이야기 추론이해능력 향상과도 관련이 있는 것으로 나타났 다. 연령이 문장의 복잡성 I단계와만 관련이 있는 것으로 나타난 것 은 본 연구의 대상자 연령이 6-9세 학령초기 연령에서 이야기 다시 말하기에 대한 표현이 아직까지는 짧은 문장 수준인 것으로 해석 할 수 있다. 즉, 다양한 표현 문장을 사용하여 이야기를 다시말하기 보다는 주인공 인물의 심리상태를 단순하게 표현하는 단계로 "he's afraid", "he thinks"와 같은 문장으로의 표현이 많이 나타난다고 볼수 있다.

$\mathrm{IQ}$ 점수는 CPLC 하위영역 중 의사소통 의도(CI) 점수와만 유의 미한 상관을 보였다 $(r=.50)$. 즉, CPLC 4 가지 하위영역인 담화관리 $(\mathrm{DM})$, 상황에 따른 조절 및 적용능력 $(\mathrm{CV})$, 의사소통 의도(CI), 비 언어적 의사소통 $(\mathrm{NC})$ 중 의사소통 의도 $(\mathrm{CI})$ 는 "궁금한 게 있으면 적절하게 질문한다, 놀이할 때 상황을 설정할 수 있다, 다양한 의문 사 질문에 적절하게 대답할 수 있다, 화해와 조정을 말로 협상할 수 있다." 등과 같은 내용으로 구성된 문항들로, 대화 상대방의 의도 를 파악하여 상황에 적절하게 말로 표현할 수 있는 고도의 언어적 능력이 요구되는 영역이다. 이러한 영역특성으로 인하여 IQ점수와 관련된 것으로 보이며, 이에 대한 추가 연구가 요구된다.

수용어휘능력점수는 표현어휘능력점수와만 유의미한 상관을 보였으나 $(r=.45)$, 표현어휘능력점수는 이야기 추론이해 $(r=.47)$ 및 총점 $(r=.44), \mathrm{CPLC}$ 하위영역 중 의사소통 의도 $(r=.46)$ 와 비언어 적 의사소통 $(r=.47)$ 영역 점수와 유의미한 상관을 보였다. 그리고 인지심성동사 사용률 $(r=-49)$ 과는 부적 상관을 보였다. 즉, 본 연구 의 대상자 연령이 학령초기인 아동들로 아동의 수용어휘능력보다 는 표현어휘능력이 이야기 이해 및 화용언어능력점수와 관련이 있 었던 것으로 해석할 수 있다. 이러한 결과를 바탕으로 해석해 본다 면 학령기 아동을 대상으로 어휘능력을 측정하는 것에 있어 표현 어휘능력을 주로 측정하는 것이 더 적절하며 효율적인 측정이 될 것으로 보인다. 그리고 인지심성동사 사용률과 표현어휘능력점수
간의 부적상관을 보인 것은 추가적인 연구가 진행되어야 해석 가능 할 것으로 보인다.

이야기 이해점수와 관련한 상관분석 결과, 추론이해점수는 이해 종합점수 $(r=.75)$, 인지동사 사용률 $(r=-.63)$ 과 관련이 있음을 확인 하였다. 그리고 이해종합점수는 인지동사 사용률과 유의미한 상관 $(r=-.53)$ 을 보였다. 이야기에 대한 사실과 추론이해점수 중 추론이 해점수만이 이해종합점수와 관련이 있었으므로 사실과 추론이해 는 구분되는 이해영역이며, 추론이해가 종합적인 이해점수와 관련 이 있음을 확인할 수 있었다. 그리고 인지동사 사용률은 추론이해 점수와 유의미한 부적상관을 보였다 $(r=-.63)$. 이는 "이해하다, 생 각하다”와 같은 인지동사를 표현에 있어 적절하게 사용하지 않고 과용한다는 것은 추론이해점수가 낮게 나타날 가능성이 있음을 시사한다. 그리고 인지동사 사용률이 이해 종합점수 $(r=-.53)$ 와 부 적상관을 보인 것은추론이해가이해 종합점수와상관이 높게 $(r=.75)$ 나타난 것과 관련된 것으로 보인다.

문장의 복잡성 단계와 관련한 상관분석 결과, 문장의 복잡성 III 단계는 이야기 사실이해점수와 부적상관을 보였으며 $(r=-.54)$, 지각 동사 사용률과는 정적상관 $(r=.43)$ 을 보였다. 그리고 문장의 복잡 성 IV단계는 인지동사 사용률 $(r=.61)$ 및 지각동사 사용률 $(r=.58)$ 과 관련이 있는 것으로 나타났다. 즉, 이야기 사실이해점수는 문장 의 복잡성 III단계와 같이 "주어+동사+목적어(the child wants to find the frog)" (Table 4) 형태의 발화 문장과 지각동사 사용률과 관련이 있다고 해석할 수 있다. 또한 대상자 연령이 6-9세로 초기 학 령기이므로 대상연령에 맞지 않는 짧은 문장 구조의 산출은 사실 이해점수와 부적상관이 있을 수 있다고 해석할 수 있다. 그리고 문 장의 복잡성 IV단계는 "he think that the frog has escaped"와 같 이 주어와 객체가 구분되는 복잡한 문장 구조로서 심리동사를 제 외한 인지 및 지각동사의 산출에 있어서는 이러한 IV단계가 적합 한 것이 아닐까 예측해 본다.

지능, 표현어휘능력점수, 심성동사 사용률과 CPLC 점수와의 상 관분석 결과, 아동 개인특성을 나타내는 변수인 IQ점수는 의사소 통 의도 $(\mathrm{CI} ; r=.50)$ 와 유의미한 상관을 보였으며, 표현어휘능력점 수는 의사소통 의도 $(\mathrm{CI} ; r=.46)$ 와 비언어적 의사소통 $(\mathrm{NC} ; r=.47)$ 점수와 유의미한 상관결과를 보였다. 그리고 심성동사 중 심리동사 와 지각동사 사용률은 CPLC 점수와 관련이 있는 것으로 나타났 다. 특히, 심리동사 사용률은 CPLC의 하위영역 중 상황에 따른 조 절능력 $(r=.45, p<.035)$ 과 의사소통 의도 $(r=.41, p<.056)$, CPLC 총점 $(r=.40, p<.065)$ 과 관련이 있었다. 그리고 지각동사 사용률은 담화관리영역과 어느 정도 관련이 있는 것으로 나타났다 $(r=.37$, $p<.094)$. 
이에 CPLC 점수들을 종속변인으로 하고 $\mathrm{IQ}$, 표현어휘능력점수, 인지, 심리, 지각 심성동사 사용률을 독립변수로 하여 단계적 회귀 분석을 진행하였다. 연구결과, IQ점수는 의사소통 의도(CI) 점수 를 유의하게 설명하고 있으며 $(t=2.583, p=.018)$, 의사소통 의도 총 변화량의 $25 \%$ 가 IQ점수에 의해 설명되고 있었다 $(F=6.67, p<.018)$. 또한 표현어휘능력점수는 비언어적 의사소통 $(\mathrm{NC})$ 점수를 유의하 게 설명하고 있으며 $(t=2.382, p<.027)$, 의사소통 의도 총 변화량의 $22 \%$ (수정결정계수에 의하면 $18 \%$ )가 IQ점수에 의해 설명되고 있 었다 $(F=5.68, p=.027)$. 이 같은 결과는 화용언어능력이란 언어영 역의 일부분으로 개인의 지능과 어휘능력과 관련이 있음을 나타내 는 의미 있는 결과이다.

그리고 심리동사 사용률은 화용언어능력 중 상황에 따른 조절 $(\mathrm{CV})$ 능력점수를 예측하는 변수로서 설명모형이 가능하며 총 변 화량의 $21 \%$ 를 설명하였다 $(F=5.12, p<.035)$. 이와 같은 연구결과 는 심성동사 사용 정도가 화용언어능력과 관련이 있다는 선행연구 들의 결과와 일치하는 것이다(Booth \& Hall, 1994; Jenkins et al., 2003; Spanoudis et al., 2007).

심성동사를 인지동사, 심리동사와 지각동사로 구분하여 살펴보 았을 때 심리동사가 화용언어점수와 유의미한 상관을 보이며 특히 화용언어 하위영역 중 상황에 따른 조절 $(\mathrm{CV})$ 능력과 유의미한 관 련이 있는 것으로 나타났다. 이러한 결과는 심리동사가 갖는 통사 적-의미적 특성과 관련이 있는 것으로 보인다. 즉, 심리동사(psychological verbs)란 화자의 내면적 심리 상태를 표현한 동사로 감정 동사라고도 하며, 특히 화자의 ‘주관적 감정'을 표현하는 어휘로 인 간이 경험하는 '감정과 직접적인 관련을 맺는다(Kim, 2004; Kim, 2009; Kim et al., 1998).

$\operatorname{Kim}$ (2004)에 의하면 ‘슬프다’라는 동사의 의미를 알기 위해서 는 ‘슬픔'이라는 감정이 무엇인지를 알아야 하고 '기쁘다'라는 동사 의 의미를 알기 위해서는 '기쁨'이라는 감정이 무엇인지를 알아야 한다. 이처럼 심리동사는 주관적 심리상태를 나타내는 술어라는 큰 틀 속에서 자신과 타인의 감정을 표현하는 동사와 형용사를 표 현할 수 있어야 사용 가능하다. 그러므로 심성동사의 다른 분류인 인지와 지각동사와는 달리 좀 더 주관적인 사고와 감정이 개입되어 야 표현 가능하다고 볼 수 있다. 이에 심성동사만이 화용언어능력 점수와 유의미한 상관을 보이고 화용언어능력점수 예측모델이 가 능했던 것으로 보인다.

화용언어체크리스트의 하위영역 중 특히 상황에 따른 조절 및 적용 $(\mathrm{CV})$ 능력과 관련을 보였다는 것도 다시 살펴볼 의미가 있다. 상황에 따른 조절 및 적용 $(\mathrm{CV})$ 능력이란 듣는 사람에 따라 존대 말이나 반말을 적절히 사용하거나 상호관계가 있는 말들(예: 가져
오다/가져가다, 빌리다/빌려주다 등)을 적절하게 사용하는 것, 농담 의 포인트를 적절하게 이해하여 반응하기, 역할 놀이에 맞게 말투 나 목소리를 바꾸기, 청자의 지식과 경험에 따라 말의 내용을 조절 할 수 있는 것과 청자가 잘 알아듣지 못했을 것을 인지하여 부연 설 명을 할 수 있는 것과 대화 중 비유어와 동음이의어를 이해할 수 있 는지 등을 측정하는 영역이다. 즉, CPLC의 다른 하위분류인 담화 관리(DM), 의사소통 의도(CI), 비언어적 의사소통(NC)과는 달리 말 그대로 대화상대방과 나와의 관계 상황을 파악하여 어떻게 상 황에 맞게 나의 언어 및 행동을 조절할 것인가 라는 화용언어부분 이다. 그러니 좀 더 타인의 상황과 감정을 이해하고 있어야 적절하 게 대처할 수 있는 화용언어영역으로 설명할 수 있다. 그러므로 인 지, 지각동사와는 구분되게 타인의 상황과 감정에 민감한 심리동 사만이 상황에 따른 조절 및 적용 $(\mathrm{CV})$ 능력과 유의미한 관련이 있 게 나타난 것이라 해석할수 있다.

심리동사 사용률은 의사소통 의도(CI; $r=.45, p<.056)$, 아동화 용언어체크리스트 총점(CPLC total; $r=.40, p<.065)$ 과도 유의미하 지는 않았지만 관련이 있는 것으로 보였다. 이러한 현상은 의사소 통 의도 $(\mathrm{CI})$ 는 상황에 따른 조절 및 적용 $(\mathrm{CV})$ 능력보다는 주로 자 신의 의도를 표현하는 능력이라는 점에서 심리동사와의 상관도가 낮게 나타난 것으로 보여진다. 그리고 담화관리(DM)와 비언어적 의사소통(NC)과는 유의미한 결과가 나타나지 않았다. 담화관리 (DM)는 먼저 대화를 시작하거나 대화 중 이해하지 못한 내용을 다 시 말해줄 것을 요청하기, 주제 유지하여 5 회 이상 말 주고받기, 다 양한 접속사를 사용하여 말을 이어가기, 상대방의 관심사에 대해 서도 언급할 수 있기 등과 같이 표면적으로 대화를 잘 이어가는 능 력을 의미한다. 그러므로 대화의 미묘한 감정적 상황 파악보다는 유연한 말 차례 이어가기로 해석할 수 있다. 이러한 영역은 심리동 사보다는 인지 및 지각동사와 같이 지각하여 알고 기억하여 추리 하는 부분에 더 적합한 것으로 보인다. 이에 담화관리 $(\mathrm{DM})$ 영역은 지각동사사용률과 어느 정도 관련이 있는 것으로 나타났다 $(r=.37$, $p<.094)$.

회귀분석 결과에서는 심리동사 사용률이 화용언어능력 중 상황 에 따른 조절능력(CV) 점수를 예측하는 변수로서 설명모형이 가 능하며 총 변화량의 $21 \%$ 를 설명하고 있음을 확인하였다 $(F=5.12$, $p=.035)$. 이 같은 결과는 연구참여자의 수가 22 명이었다는 제한점 으로 인해 설명력이 높은 편은 아니지만 특정 어휘를 사용하는 정 도가 화용언어능력과 관련이 있고 또한 예측도 가능하다는 유의미 한 결과가 나왔다는 데 의미가 있다.

이를 임상현장에 적용해 본다면, 화용언어능력에 문제가 있는 아동들에게 심리동사를 다양하게 문장 속에서 읽고 이해하는 훈 
련이 진행된다면 아동의 화용언어능력 증진에 도움이 될 것이고 심 성어휘를 이용한 화용언어평가도 가능하지 않을까 생각해 본다. 그 러므로 앞으로 심성동사에 대한 평가과제 제작 및 훈련과제에 대 한 연구가 계속 진행되어야 할 것이다.

\section{REFERENCES}

Baker, C. F. (1999). Seeing clearly: frame semantic, psycholinguistic, and crosslinguistic approaches to the semantics of the English verb see (Doctoral dissertation). University of California, Berkeley, CA.

Bartsch, K., \& Wellman, H. M. (1995). Children talk about the mind. New York, NY: Oxford University Press.

Baumgartner, E., Biagini, E., \& Devescovi, A. (1998). Psychological language recursiveness in children's narratives. Psychology of Language and Communication, 2(2), 57-62.

Booth, J. R., \& Hall, W. S. (1994). Role of the cognitive internal state lexicon in reading comprehension. Journal of Educational Psychology, 86(3), 413422.

Bretherton, I., \& Beeghly, M. (1982). Talking about internal states: the acquisition of an explicit theory of mind. Developmental Psychology, 18(6), 906921.

Byun, J. M. (2002). The category of cognitive verb. Korean linguistics, 16, 307332.

Dyer-Seymour, J. R., Shatz, M., Wellman, H. M., \& Saito, M. T. (2004). Mental state expressions in US and Japanese children's books. International Journal of Behavioral Development, 28(6), 546-552.

Dyer, J. R., Shatz, M., \& Wellman, H. M. (2000). Young children's storybooks as a source of mental state information. Cognitive Development, 15(1), 1737.

Evans, N., \& Wilkins, D. (2000). In the mind's ear: The semantic extensions of perception verbs in Australian languages. Language, 76(3), 546-592.

Felser, C. (1998). Perception and control: a minimalist analysis of English direct perception complements. Journal of Linguistics, 34(2), 351-385.

Hutchins, T. L., Bond, L. A., Silliman, E. R., \& Bryant, J. B. (2009). Maternal epistemological perspectives and variations in mental state talk. Journal of Speech, Language, and Hearing Research, 52(1), 61-80.

Jenkins, J. M., Turrell, S. L., Kogushi, Y., Lollis, S., \& Ross, H. S. (2003). A longitudinal investigation of the dynamics of mental state talk in families. Child Development, 74(3), 905-920.

Johnson, C. N., \& Wellman, H. M. (1980). Children's developing understand- ing of mental verbs: remember, know, and guess. Child Development, 51(4), 1095-1102.

Kim, E. Y. (2004). A study of Korean emotion verbs (Doctoral dissertation). Chonnam national University, Gwangju, Korea.

Kim, Y., Kim, J. K., Park, S. K., Oh, K. J., \& Chung, C. S. (1998). Dimension of the emotion structure through the analyses of emotion related terms in Korean language. Korean Journal of the Science of Emotion \& Sensibility, 1(1), 145-152.

Kim, Y. J. (2009). The early acquisition of affect lexicon in Korean and the saliency of double-nominative constructions. Korean Journal of Linguistics, 34(3), 441-472.

Kim, Y. T., Hong, G. H., Kim, K. H., Jang, H. S., \& Lee, J. Y. (2009). Receptive \& expressive vocabulary test (REVT). Seoul: Seoul Community Rehabilitation Center.

$\mathrm{Ku}$ J. H. (2008). Study on the potential of narrative learning for the school-aged children with Down syndrome through dynamic assessment (Master's thesis). Ewha Womans University, Seoul, Korea.

Kwak, K. C., Park, H. W., \& Kim, C. T. (2001). Korean Wechsler intelligence scale for children-III (K-WISC-III). Seoul: Seoul Special Education Publishing Co.

Lee, E. J. (2011). Development and developing organization of mental verbs in children of deaf parents (CODA) (Doctoral dissertation). Ewha Womans University, Seoul, Korea.

Lee, E. J., \& Kim, Y. T. (2011a). Development of mental verbs in children of deaf adults (CODA). Korean Journal of Communication \& Disorders, 16(4), 503-520.

Lee, E. J., \& Kim, Y. T. (2011b). Developing organization of cognitive verbs in children of deaf parents. Discourse and Cognition, 18(2), 89-111.

Lee, J. W. (2004). Theory of mind and acquisition of Korean verbs (Master's thesis). Yonsei University, Seoul, Korea.

Mayer, M. (1969). Frog, where are you? New York, NY: Dial Book for Young Readers.

Montgomery, D. E. (2002). Mental verbs and semantic development. Journal of Cognition and Development, 3(4), 357-384.

Moore, C., Bryant, D., \& Furrow, D. (1989). Mental terms and the development of certainty. Child Development, 60(1), 167-171.

Nguyen, L., \& Frye, D. (1999). Children's theory of mind: understanding of desire, belief and emotion with social referents. Social Development, 8(1), 70-92.

Oh, S., Lee, E. J., \& Kim, Y. T. (2012). Preliminary study on developing test 
items of children’s pragmatic language checklist. Journal of Speech \& Hearing Disorders, 21(2), 111-135.

Oh, S. J. (2018). Validity study on children's pragmatic language checklist (CPLC). Journal of Speech-Language \& Hearing Disorders, 27(2), 125-134.

Pae, S., Kwon, E., \& Jin, Y. (2018). Korean Narrative Assessment (KONA). Seoul: Hakjisa.

Park, H., Kwak, K., \& Park, K. (1997). Korean-Wechsler Preschool and Primary Scale of Intelligence (K-WPPSI). Seoul: Seoul Community Rehabilitation Center.

Perovic, A., \& Wexler, K. (2010). Development of verbal passive in Williams syndrome. Journal of Speech, Language, and Hearing Research, 53(5), 12941306.

Quirk, R. (1985). A comprehensive grammar of the English language. London: Longman.

Ruffman, T., Slade, L., \& Crowe, E. (2002). The relation between children's and mothers' mental state language and theory-of-mind understanding. Child Development, 73(3), 734-751.

Safir, K. (1993). Perception, selection, and structural economy. Natural Language Semantics, 2(1), 47-70.

Schwanenflugel, P. J., Fabricius, W. V., \& Noyes, C. R. (1996). Developing or- ganization of mental verbs: evidence for the development of a constructivist theory of mind in middle childhood. Cognitive Development, 11(2), 265294.

Schwanenflugel, P. J., Henderson, R. L., \& Fabricius, W. V. (1998). Developing organization of mental verbs and theory of mind in middle childhood: evidence from extensions. Developmental Psychology, 34(3), 512-524.

Shatz, M., Wellman, H. M., \& Silber, S. (1983). The acquisition of mental verbs: a systematic investigation of the first reference to mental state. Cognition, 14(3), 301-321.

Spanoudis, G., Natsopoulos, D., \& Panayiotou, G. (2007). Mental verbs and pragmatic language difficulties. International Journal of Language \& Communication Disorders, 42(4), 487-504.

Strong, C. (1998). The strong narrative assessment procedure. Eau Claire, WI: Thinking Publications.

Viberg, Å. (1983). The verbs of perception: a typological study. Linguistics, 21(1), 123-162.

Yang, S. J. (2000). The development of cohesion in the narratives of Korean-speaking children aged 4, 6, 8, and adults (Master's thesis). Ewha Womans University, Seoul, Korea. 
Appendix 1. Example of story picture scene

\section{장면 1}

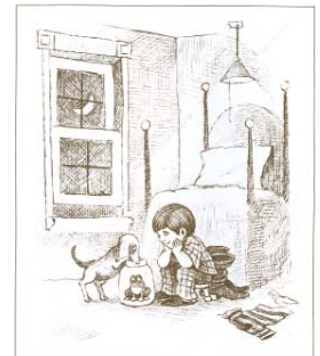

5

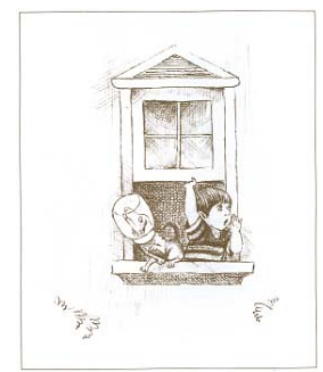

9

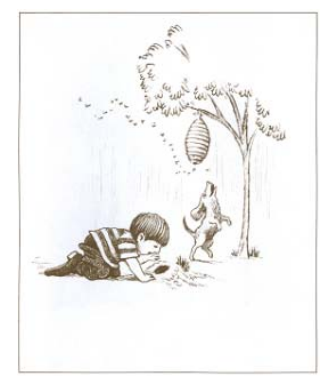

13

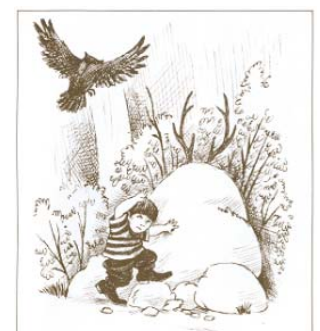

2

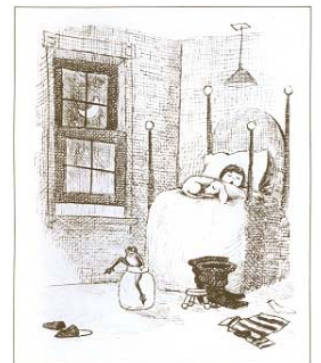

6

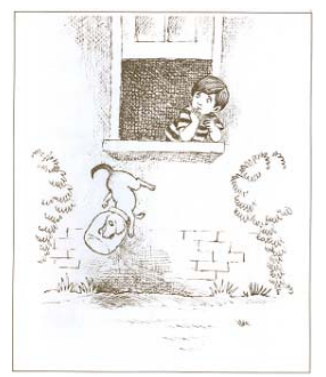

10

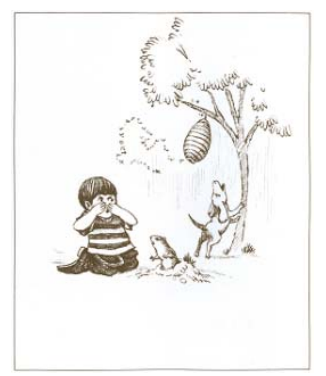

14

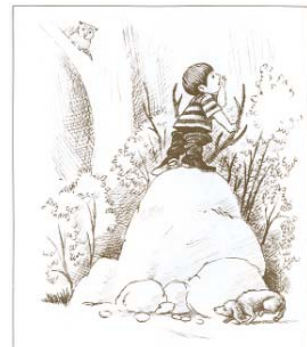

3

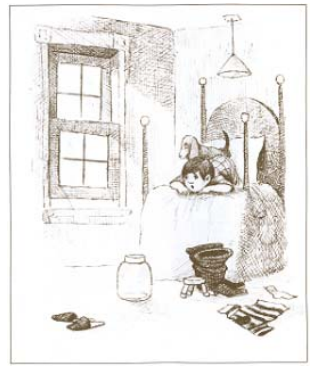

7

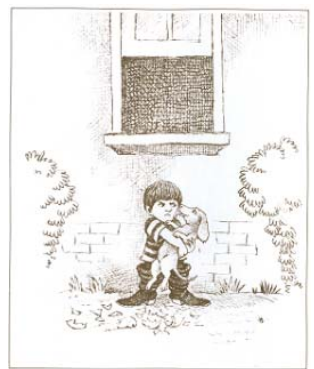

11

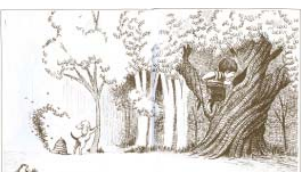

15

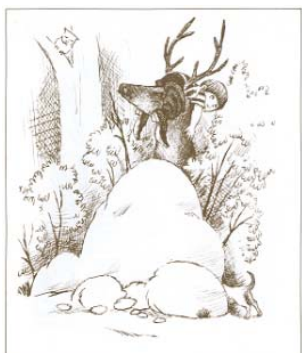

4

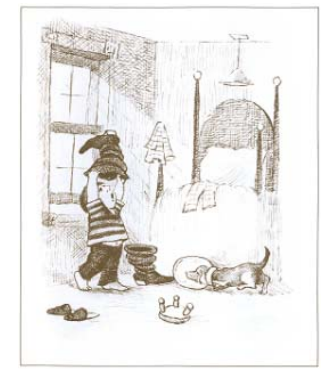

8

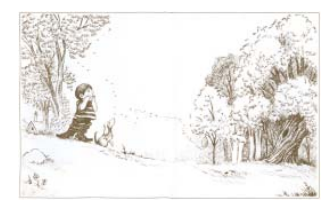

12

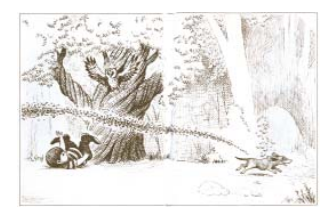

16

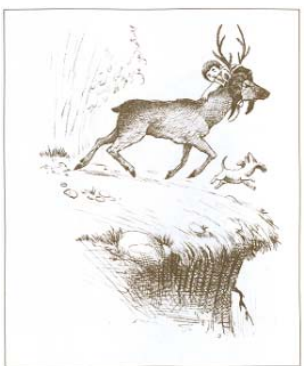

Source from Mayer (1969). 
Eun Ju Lee - The Relation between Mental Verbs Utilization and CPLC

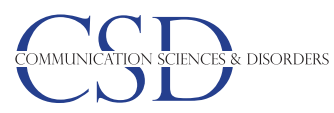

Appendix 2. Example of mental verbs in the story

\begin{tabular}{|c|c|c|c|c|}
\hline Picture number & C-unit & Clauses & Story grammar code & Anecdotes \\
\hline \multirow[t]{2}{*}{1} & 1 & 옛날에 애완용 개구리를 기르는 민우라는 소년이 있었습니다. & 배경 & 1 \\
\hline & 2 & 그 소년은 개구리를 커다란 유리병에 넣어두었습니다. & 배경 & \\
\hline \multirow[t]{3}{*}{2} & 3 & 어느 날 밤, 소년과 강아지가 잠이 든 사이에, & 배경 & \\
\hline & & 개구리는 유리병을 타고 올라가 병 밖으로 나왔습니다. & 계기사건 1 & \\
\hline & 4 & 그리고는 열려 있는 창문을 통해 빠져 나갔습니다. & 계기사건 2 & \\
\hline \multirow[t]{2}{*}{3} & 5 & 아침잠에서 깬 민우는 침대에 엎드려 개구리에게 인사를 하려고 했습니다. & 배경 & \\
\hline & 6 & 그런데 개구리가 없었습니다. & 계기사건 3 & \\
\hline \multirow[t]{2}{*}{4} & 7 & 민우는 개구리를 찾기 위해 이곳 저곳을 살펴보았습니다. & 시도 1 & \\
\hline & 8 & 그리고 강아지도 개구리를 찾아보았습니다. & 시도 2 & \\
\hline \multirow[t]{3}{*}{5} & 9 & 민우는 창문 밖으로 개구리를 불러보았습니다. & 시도 3 & \\
\hline & 10 & 강아지는 병 속을 들여다보다가, & 배경 & \\
\hline & & 그만 머리가 병 속에 끼었습니다. & 결과 1 & \\
\hline \multirow[t]{2}{*}{6} & 11 & 그리고 강아지가 창문에 기대었을 때, & 배경 & \\
\hline & & 무거운 병 때문에 강아지는 창문 아래로 떨어졌습니다. & 결과 2 & \\
\hline \multirow[t]{3}{*}{7} & 12 & 그래서 병이 깨졌습니다. & 결과 3 & \\
\hline & 13 & 민우는 강아지를 안고 괜찮은지 살펴보았습니다. & 내적 반응 & \\
\hline & 14 & 그리고 강아지는 고마워서 소년을 핢았습니다. & 내적 반응 & \\
\hline 8 & 15 & 하루 종일 민우는 개구리를 부르며 찾아다녔습니다. & 시도 1 & 2 \\
\hline 9 & 16 & 소년은 땅 구멍 속을 들여다보며 개구리를 불렀습니다. & 시도 2 & \\
\hline \multirow[t]{4}{*}{10} & 17 & 두더지는 귀찮다면서 민우한테 화를 냈습니다. & 내적 반응 & \\
\hline & 18 & 그리고 민우가 나무구멍 속을 살펴보면서 개구리를 부르는 동안, & 시도 3 & \\
\hline & & 강아지는 계속해서 문제를 일으켰습니다. & 시도 4 & \\
\hline & 19 & 강아지는 벌집을 보고 짖으며, 벌집이 달려 있는 나무에 뛰어올랐습니다. & 배경/시도 5 & \\
\hline 11 & 20 & 그러자 벌집이 떨어져버렸습니다. & 결과 1 & \\
\hline
\end{tabular}

Source from Strong (1998). 


\section{국문초록}

\section{이야기 다시 말하기 과제에서의 심성동사(mental verb) 사용률과 아동화용언어체크리스트(CPLC) 점수와의 관련성} 이은주

이화여자대학교 언어병리학과

배경 및 목적: 심성동사는 아동의 의사소통 및 언어발달과 관련이 있으며 특히 읽기이해 및 화용언어능력과 관련이 있다. 이에 일반아 동 집단을 대상으로 이야기 과제에서의 심성동사 사용률과 아동화용언어체크리스트(CPLC)의 점수 간에 관련이 있는지를 살펴보고 자 한다. 방법: 일반아동 22 명의 ‘이야기 다시말하기’ 과제에서의 이야기이해점수, 심성동사 유형별 사용률 및 이야기 발화 문장 복잡성 단계별 심성동사 사용률과 CPLC 4가지 하위영역별 점수 간의 관련성을 Pearson 적률 상관분석(Pearson product-moment correlation analysis)을 통해 살펴보았다. 그리고 위의 상관연구결과를 통해 유의미한 상관을 보이는 변수들을 통해 화용언어능력점수를 예측해 줄 수 있는 설명모형이 가능한지를 회귀분석(regression analysis)을 통해 살펴보았다. 결과: 지능, 표현어휘능력점수, 심성동사 사용률 과 $\mathrm{CPLC}$ 점수와의 상관분석 결과, $\mathrm{IQ}$ 점수는 의사소통 의도 $(\mathrm{CI} ; r=.50)$ 와 유의미한 상관을 보였으며, 표현어휘능력점수는 의사소통 의 도 $(\mathrm{CI} ; r=.46)$ 와 비언어적 의사소통 $(\mathrm{NC} ; r=.47)$ 점수와 유의미한 상관결과를 보였다. 그리고 심성동사 중 심리동사와 지각동사 사용 률은 CPLC 점수와 관련이 있는 것으로 나타났다. CPLC 점수들을 종속변인으로 하고 $\mathrm{IQ}$, 표현어휘능력점수, 인지, 심리, 지각 심성동사 사용률을 독립변수로 하여 단계적 회귀분석을 진행한 결과, IQ점수는 의사소통 의도 $(\mathrm{CI})$ 점수를 유의하게 설명하고 있으며 $(t=2.583$, $p=.018)$, 표현어휘능력점수는 비언어적 의사소통(NC) 점수를 유의하게 설명하였다 $(t=2.382, p=.027)$. 이 같은 결과는 화용언어능력 이란 언어영역의 일부분으로 개인의 지능과 어휘능력과 관련이 있음을 나타내는 의미 있는 결과이다. 그리고 심리동사 사용률은 화용 언어능력 중 상황에 따른 조절(CV) 능력점수를 예측하는 변수로서 설명 모형이 가능하며 총 변화량의 $21 \%$ 를 설명하였다 $(F=5.12$, $p=.035)$. 논의 및 결론: 연구참여자의 수가 22 명이었다는 제한점으로 인해 설명력이 높은 편은 아니지만 특정 어휘를 사용하는 정도 가 화용언어능력과 관련이 있고 또한 예측도 가능하다는 결과가 나왔다는 데 의미가 있다.

핵심어: 심성동사, 심리동사, 이야기 다시말하기, 화용언어, CPLC

본 논문은 제 1 저자의 박사학위논문의 일부를 발췌하였음.

본 연구는 정부(교육부)의 재원으로 BK21 플러스 사업의 지원을 받아수행된 연구임.

\section{참고문헌}

곽금주, 박혜원, 김청택(2001). 한국판 웩슬러 아동용 지능검사(K-WISC-III). 서울: 도서출판특수교육.

구지혜(2008). 역동적 평가를 통한 학령기 다운증후군 아동의 이야기 학습 잠재력 연구. 이화여자대학교 대학원 석사학위논문.

김영아, 김진관, 박수경, 오경자, 정찬섭(1998). 정서관련 어휘 분석을 통한 내적 상태의 차원 연구. 감성과학, 1(1), 145-152.

김영주(2009). 국어감정 어휘의 습득. 언어, 34(3), 441-472.

김영태, 홍경훈, 김경희, 장혜성, 이주연(2009). 수용·표현어휘력검사(REVT). 서울: 서울장애인종합복지관.

김은영(2004). 국어 감정동사 연구. 전남대학교 대학원 박사학위논문.

박혜원, 곽금주, 박광배(1997). 한국-웩슬러 유아지능검사(K-WPPSI). 서울: 도서출판 특수교육.

배소영, 권유진, 진연선(2018). KONA 한국어 이야기평가. 서울: 학지사.

변정민(2002). 인지 동사의 범주. 한국어학, 16, 307-332.

양수진(2000). 이야기 결속표지 발달: 4 세, 6 세, 8 세 및 성인을 대상으로. 이화여자대학교 대학원 석사학위논문.

오소정(2018). 아동화용언어체크리스트(CPLC)의 타당도 연구. 언어치료연구, 27(2), 125-134. 
오소정, 이은주, 김영태(2012). 화용능력 체크리스트 문항 개발을 위한 예비 연구. 언어치료연구, 21(2), 111-135.

이은주(2011). 청각장애부모 가정 건청자녀의 심성동사 발달 및 의미구조화: 수화사용부모를 중심으로. 이화여자대학교 대학원 박사학위논문.

이은주, 김영태(2011a). 청각장애부모 가정 건청아동 집단의 심성동사 어휘발달. 언어청각장애연구, 16(4), 503-520.

이은주, 김영태(2011b). 수화사용 청각장애부모 가정 건청자녀의 인지심성동사 의미 구조화 발달. 담화와 인지, 18(2), 89-111.

이재원(2004). 마음 이론과 한국어 동사의 습득. 연세대학교 대학원 석사학위논문.

\section{ORCID}

이은주(https://orcid.org/0000-0003-2976-3151) 